INSPECTION REPORT

\section{The Fiscal Year 1996 Performance Based Incentive Program at the Savannah River Operations Office}

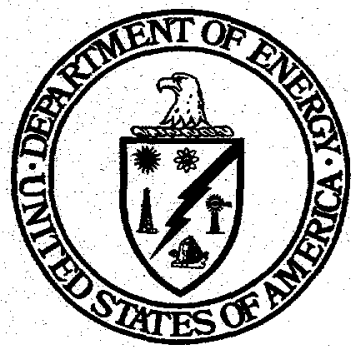

U.S. DEPARTMENT OF ENERGY OFFICE OF INSPECTOR GENERAL OFFICE OF AUDIT SERVICES 


\section{DISCLAIMER}

This report was prepared as an account of work sponsored by an agency of the United States Government. Neither the United States Government nor any agency thereof, nor any of their employees, makes any warranty, express or implied, or assumes any legal liability or responsibility for the accuracy, completeness, or usefulness of any information, apparatus, product, or process disclosed, or represents that its use would not infringe privately owned rights. Reference herein to any specific commercial product, process, or service by trade name, trademark, manufacturer, or otherwise does not necessarily constitute or imply its endorsement, recommendation, or favoring by the United States Government or any agency thereof. The views and opinions of authors expressed herein do not necessarily state or reflect those of the United States Governmeat or any agency thereof. 


\section{DISCLAIMER}

Portions of this document may be illegible electronic image products. Images are produced from the best available original document. 


\section{INSPECTION OF THE FISCAL YEAR 1996 \\ PERFORMANCE BASED INCENTIVE PROGRAM \\ AT THE SAVANNAH RIVER OPERATIONS OFFICE}

\section{TABLE OF CONTENTS}

\section{Overview}

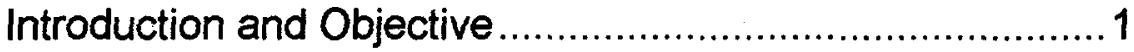

Observations and Conclusions ..............................................

Findings and Recommendations ................................ 4

Savannah River PBI Program Experienced Similar

Problems.

Questionable PBI Fee Payments.

1. Two PBI Fees Paid For Achieving Minimal Cost Savings

Recommendation 1 and Management Comment

Inspector Comment

2. PBI Fee Paid For Work Which Did Not Meet PBl's

Stated Requirement.

3. New Sources of Funding Were Double-Counted

Towards Two PBIs

Recommendation 2 and Management Comment

Inspector Comment

\section{Appendix}

Scope.

Methodology

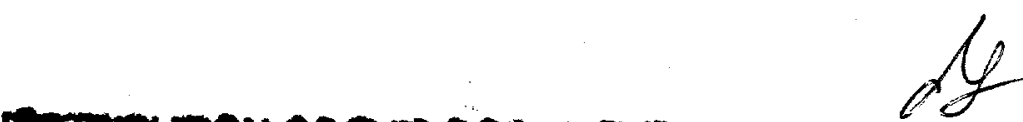


INTRODUCTION AND OBJECTIVE
In June 1993, the then Secretary of Energy established a Contract Reform Team to review the Department of Energy's (DOE) contracting practices and to make recommendations to improve them. The need for contract reform was driven by a recognition that DOE did not have adequate control of its contractors, that contractors were not sufficiently accountable to DOE, and that there was an absence of well-defined performance measures and criteria for DOE contractors.

In February 1994, DOE's Contract Reform Team issued its report entitled Making Contracting Work Better and Cost Less. A key recommendation of the Contract Reform Team's report was the establishment of a new form of Management and Operating (M\&O) contract-the Performance Based Management Contract. The fundamental component of this new approach to contracting is the use of performance based contracting concepts, which emphasizes more definitive statements of work, specific performance objectives and measures, and linkage to appropriate performance incentives. Simply put, the purpose of performance based contracts is to clearly state what the Department expects from its contractors, establish financial incentives that motivate the contractors to perform, and provide ways for the Department to measure their performance.

The thrust of the Contract Reform Team's efforts was consistent with the August 1993 Government Performance Results Act which focused on improving the management of Federal programs and activities by establishing program goals and measuring the achievement of these goals.

The Office of Inspector General has previously issued three reports dealing with implementation of performance based contracting within the Department of Energy. Our reports documented deficiencies in the Department's development and administration of performance based contracts and the associated incentives used to improve contractor performance. In report DOE/IG-0401, "Inspection of the Performance Based Incentive Program at the Richland Operations Office," we cited numerous Performance Based Incentive (PBI) Program weaknesses in the implementation of the Fiscal Year 1995 PBI Program at Richland. As a result of our inspection, Richland's 
contractor agreed to reimburse DOE $\$ 2.5$ million in performance fees and penalties.

In report DOE/IG-0411, "Audit of the Contractor Incentive Programs at the Rocky Flats Environmental Technology Site," we found that the Rocky Flats Field Office rewarded the contractor for cost reduction proposals that were not innovative and that these proposals generally did not result irı savings being returned to the Department. We also found that the performance measures at Rocky Flats rewarded performance expectations that were not clearly defined and were not always structured so as to encourage and reward superior performance by the contractor.

In report DOE/IG-0412, "Audit of the Contractor Incentive Program at the Nevada Operations Office," we found that the performance measures included milestones that were established after the work had actually been completed, and that criteria established to meet the performance measures were vague and non-specific.

The Department took action in response to these reports. Shortly after taking office in March 1997, the Secretary received the Inspector General's "Report on Inspection of the Performance Based Incentive Program at the Richland Operations Office." Immediately thereafter, the Secretary directed the initiation of a comprehensive review of performance based incentives to determine the scope and magnitude of implementation problems across the Department. This review entitled "ASSESSMENT OF THE USE OF PERFORMANCEBASED INCENTIVES IN PERFORMANCE-BASED MANAGEMENT AND MANAGEMENT AND INTEGRATION CONTRACTS," completed in October 1997, identified systemic problems in the implementation of performance based incentives and resulted in a corrective action plan which included the following key elements:

- The issuance of additional direction to DOE field organizations to strengthen the organizational structure, processes, and criteria for the administration of performance based incentives; 
- The issuance of new guidance and instructional information on the use of performance based incentives;

- The establishment of support mechanisms to assist contracting activities in the development and use of performance based incentives; and

- The establishment of an aggressive schedule for the necessary corrective actions as well as feedback mechanisms to ensure that the actions are effective.

Also in March 1997, we initiated a review of the Fiscal Year 1996 Performance Based Incentive Program at the Savannah River Operations Office (Savannah River). This incentive program provided its M\&O contractor, Westinghouse Savannah River Company (Westinghouse), with an opportunity to earn $\$ 26.28$ million in incentive fees. The objective of our review was to determine the adequacy of the Fiscal Year 1996 Performance Based Incentive Program at Savannah River and to determine if the performance fees awarded were appropriate.

OBSERVATIONS AND CONCLUSIONS
Our inspection determined that Savannah River has experienced problems with the establishment and implementation of individual performance based incentives similar to the problems we identified in our earlier reviews at other DOE sites. We also found that certain PBI fee payments appeared questionable. In one instance, involving the double counting of new funding towards achieving two PBIs, we recommended that the PBIs be reviewed for possible recovery of improperly paid fee. 


\section{Savannah River PBI Program Experienced Similar Problems}

\author{
Savannah River \\ Experienced Problems \\ Similar To Those Identified \\ In Three Previous Office Of \\ Inspector General Reviews
}

The Fiscal Year 1996 Performance Based Incentive (PBI) Program at the Savannah River Operations Office experienced problems similar to those identified in the three previous Office of Inspector General reviews. For example, the Fiscal Year 1996 PBI Program at Savannah River was established without any specific written policies or procedures for the management and administration of an incentive fee program, and the Performance Evaluation Plan which contained the Fiscal Year 1996 performance based incentives was not approved until February 14, 1996, four and one-half months into the performance period. Savannah River officials attributed this delay to the learning curve associated with implementing the new incentive fee program. Our review also revealed that the Savannah River PBI program experienced some weaknesses in the management and administration of individual F'Bls similar to those found by the Office of Inspector General at cther sites. The following weaknesses did not occur in every instance, but were detected during the review:

- PBI performance objectives were poorly defined.

- PBI performance objectives were easy to achieve and did not "stretch" the contractor.

- The expected financial and operational benefits from individual projects selected under the PBI program were undefined.

- $\mathrm{PBI}$ fees appeared to be inappropriate when compared with the direct cost of performing the work.

- The rationale used to determine specific PBI fee amounts was unclear.

- PBI work was accomplished prior to the PBIs being formally established and approved.

- The rationale for PBI modifications was not fully documented. 
- Documentation to support the validation and acceptance of PBI work was incomplete.

The Department Has Made Progress
Recently, the Department of Energy has made progress in the development and issuance of policy and procedural guidance on the management and administration of incentive fee programs. Examples of this guidance include:

- The "Environmental Management Guidelines for Fee and Incentive Development" was issued by the Assistant Secretary for Environmental Management on July 11, 1997. These guidelines address the fee structure, the use of stretch goals, the need for clear definition of work and acceptance criteria, and documentation of changed performance criteria and Department verification of the PBI work performed by the contractor.

- Acquisition Letter 97-06 issued by the Department on August 28, 1997, stated that Heads of Contracting Activities shall establish a process internal to their organization to assess all performance objectives and fees. This process is to ensure that performance objectives are well-defined and rational, and that mechanisms exist as part of contract administration for validation of contractor performance against the stated objectives.

- The Savannah River Operations Office "Performance Based Incentive (PBI) Policy and Procedures" was developed as part of the Fiscal Year 1998, "Performance Evaluation Plan" for the Westinghouse Savannah River Company contract. The policy and procedures address the development of performance based incentives, the validation and payment of completed performance based incentives, and modifications to performance based incentives. 
- Acquisition Letter 97-08 issued by the Department on December 8, 1997, provided guidance on the structuring of performance based incentive arrangements in Performance Based Management Contracts, and established general requirements for formal administrative processes and procedures relating to performance based incentives.

The Department has recognized, however, that Departmentwide and local implementing guidance on the development and administration of performance objectives and related incentives was limited and, generally, did not address certain issues such as properly allocating fee amounts to specific incentives. In the Department's October 1997 Report to the Secretary on the "ASSESSMENT OF THE USE OF PERFORMANCE-BASED INCENTIVES IN PERFORMANCEBASED MANAGEMENT AND MANAGEMENT AND INTEGRATION CONTRACTS," the Office of Procurement and Assistance Management recommended that the Department strengthen its framework of directives and instructional information on the use of performance based incentives. We believe that this action, in conjunction with the existing policy and procedural guidance on incentive fee programs, should address the types of problems discussed above, and if fully implemented at Savannah River, should prevent these problems from reoccurring. 
Three Instances Of Questionable Fee

Payments
Our inspection disclosed three instances of questionable fee payments. These three instances were: 1) $\$ 2,145,000$ of fee paid for achieving minimal cost savings; 2) $\$ 380,000$ paid for work which did not meet a PBl's stated requirement; and 3) double counting $\$ 3,280,000$ in new sources of funding towards achieving two PBls.

PBI 96-6, entitled "Meet all Regulatory Commitments/ Expectations," had the objective of meeting all Fiscal Year 1996 regulatory commitments for the local Environmental Restoration (ER) program, but at less cost when compared to an approved December 1993 Baseline for performing this work. This PBI provided for two incentive fee levels: a "Superior" fee of $\$ 1,445,000$; or an "Excellent" fee of $\$ 500,000$. The "Superior Performance Standard" for PBI $96-6$, for a fee of $\$ 1,445,000$, required that Westinghouse:

"Meet all ER [Environmental Restoration] commitments/ expectations including those listed in FFA Appendix $\mathrm{H}$ and $D$, revised RCRA operating permit, settlement agreements, administrative orders, consent decrees, NODs [Notice of Deficiency], NOVs [Notice of Violation], or notices of regulatory direction and closure plans at a 25 percent cost savings compared to the approved December 1993 Baseline." [Emphasis Added.]

The "Excellent Performance Standard," for a fee of $\$ 500,000$, had the same requirements as the "Superior Performance Standard," except that the cost savings requirement was reduced to 20 percent of the approved December 1993 Baseline.

Our inspection found, however, that Savannah River awarded Westinghouse the "Superior" fee of $\$ 1,445,000$ based upon Westinghouse achieving only a 10 percent cost savings compared to the approved December 1993 Baseline. This was well short of the 25 percent cost savings required under the PBl's "Superior Performance Standard." Specifically, data provided by Westinghouse showed that the December 1993 Baseline cost of work performed in Fiscal Year 1996 was \$139.9 million. Westinghouse was paid the "Superior" fee of $\$ 1,445,000$ after achieving a cost savings of $\$ 14$ million. This $\$ 14$ million cost savings represented a savings of only 10 percent of the approved December 1993 Baseline costs. 
Payment of the "Superior" fee occurred because the cost savings target in the "Performance Criteria" was not consistent with the cost savings requirements in the PBI's "Performance Standards." The "Performance Criteria" stated that:

"This goal requires WSRC [Westinghouse Savannah River Company] to achieve a 25 percent productivity' improvement in the unit cost of performing work scope by September 30, 1996. The improvement is estimated to be a total of $\$ 26.2$ million. The actuals for FY95 are $\$ 12.2 \mathrm{M}$ and the target for FY96 is $\$ 14.0 \mathrm{M}$. Cost savings are calculated by comparing the unit cost of work scope performed in the FY96 AOP [Annual Operational Plan] to the December 1993 baseline or equivalent estimates. If work scope is moved out of the AOP (via changes), the cost savings of 25 percent will be measured against the new cost of remaining scope."

In an effort to determine what performance level was actually intended, we discussed this issue with Savannah River officials. In interviews with the Contracting Officer and the Assistant Manager for Environmental Quality, both officials told us that in order for Westinghouse to have earned either a "Superior " fee or an "Excellent" fee for this PBI, Westinghouse would had to have met the appropriate "Performance Standard" for each fee level. That is, a "Superior" fee required a cost savings of 25 percent, and an "Excellent" fee required a cost savings of 20 percent.

Our analysis showed that Westinghouse's claimed savings of $\$ 14$ million, which was achieved in July 1996, represented a savings of only 10 percent of the approved December 1993 Baseline costs. Thus, the claimed savings failed to meet the "Performance Standards" of PBI 96-6. Nonetheless, Savannah River awarded Westinghouse a "Superior" performance fee of $\$ 1,445,000$.

Having achieved the $\$ 14$ million savings "target" in July 1996, Westinghouse continued to achieve additional savings through the remainder of Fiscal Year 1996. By the end of Fiscal Year 1996, Westinghouse had incurred $\$ 114.3$ million in costs on environmental work originally estimated to cost $\$ 139.9$ million in 
the approved December 1993 Baseline. This resulted in a total claimed cost savings of $\$ 25.6$ million for Fiscal Year 1996.

Although Westinghouse's $\$ 25.6$ million in total savings was greater than the $\$ 14$ million "target" used as the basis for awarding Westinghouse a "Superior" fee, it still only represented a savings of 18.3 percent of the December 1993 Baseline costs. This 18.3 percent savings failed to meet either the "Superior Performance Standard" of 25 percent, or the "Excellent Performance Standard" of 20 percent for PBI 96-6.

As part of our Inspection, we also evaluated the contractor's performance under PBI 96-18, entitled, "Improve Environmental Restoration Productivity." The specific objective of this incentive was to, "Further improve productivity above the superior rating of PBI Area 6 [PBI 96-6] and use those savings to execute additional scope in FY96." In essence, PBI 96-18 was intended to achieve savings which supplemented those claimed under PBI 96-6. The new PBI was funded at a maximum fee of $\$ 700,000$, using "recycled" incentive fee dollars from other PBIs that had not been earned by Westinghouse earlier in the fiscal year. The fee schedule for PBI 96-18 was complex. In summary, Westinghouse could earn a maximum additional incentive of $\$ 700,000$ if it achieved total cost savings of $\$ 21$ million, or $\$ 7$ million more than the $\$ 14$ million "target" used as the basis for awarding a "Superior" fee for PBI 96-6.

The $\$ 14$ million savings "target" in PBI 96-6's "Performance Criteria" was referenced by PBI $96-18$ as the starting point for exceeding the superior performance rating of PBI 96-6. Using this starting point, the total cost savings requirement for $\mathrm{PBI}$ 9618 was set at $\$ 21$ million in order to earn maximum fee of $\$ 700,000$. Westinghouse claimed that the $\$ 21$ million cost savings requirement for $\mathrm{PBI}$ 96-18 was exceeded in September 1996, the last month of the fiscal year. Accordingly, Savannah River awarded the contractor the maximum incentive fee of $\$ 700,000$.

We concluded that the process for developing and executing PBI 96-18 was flawed. First, as noted in our analysis of PBI 966 , the use of $\$ 14$ million in cost savings as the starting point for the supplemental incentive was inappropriate. The "Superior Performance Standard" required a 25 percent cost savings 
Fiscal Year 1996 Cost Savings Summary compared to the approved December 1993 Baseline; this computed to a cost savings of about $\$ 34.9$ million. If there was to be a supplemental cost savings incentive, this 25 percent cost savings of PBI 96-6's "Superior Performance Stanclard" should have been the starting point for measuring additional savings. Second, the justification for an additional PBI for cost savings was questionable. The period of performance for F'BI 96-6 was the same as for PBI 96-18, namely, all of Fiscal Year 1996. Both this incentive and PBI 96-18 also had the same basic objective of achieving cost savings. Further, while we disagree with the contention that only $\$ 14$ million in cost savings satisfied the "Superior Performance Standard" of PBI 96-6, Westinghouse's data indicated that the contractor achieved this savings level in July 1996. This raises what we believe is a reasonable question - why should it be necessary to further incentivize the contractor's "Superior" performance record for the period between July and September 1996?

In summary, Westinghouse was rewarded for "Superior" performance for achieving Fiscal Year 1996 cost savings of $\$ 21$ million, the first $\$ 14$ million as part of PBI $96-6$, and the remaining $\$ 7$ million under $\mathrm{PBI}$ 96-18. In fact, Westinghouse actually exceeded the $\$ 21$ million, and claimed $\$ 25.6$ million in total savings for Fiscal Year 1996. In analyzing the data, however, we found that Westinghouse needed cost savings of more than $\$ 34.9$ million, or 25 percent of the $\$ 139.9$ million December 1993 Baseline work performed in Fiscal Year 1996, to have improved productivity above the "Superior Performance Standard" of PBI 96-6. Further, when Westinghouse's total claimed cost savings of $\$ 25.6$ million for Fiscal Year 1996 are considered, Westinghouse fell far short of the 25 percent standard for "Superior" performance for PBI 96-6, and even missed the 20 percent standard for "Excellent" performance, which would have required a cost savings of almost $\$ 28$ million.

In a draft of this report, we had concluded that the incentive fees paid for both PBI 96-6 and PBI 96-18 should be recovered. We had based this, in part, on statements by two Savannah River officials, that in order for Westinghouse to have earned either a "Superior "fee or an "Excellent" fee for PBI 96-6, Westinghouse would have had to have met the appropriate "Performance Standard" for each fee level. And the required cost savings for the "Superior Performance Standard" was stated to be 25 percent, not $\$ 14$ million. 
In commenting on the draft report, however, the Acting Manager, Savannah River wrote that this PBI was very difficult to understand; and that it had been the intent and understanding of both Savannah River and Westinghouse, based on a two-year goal, that if Westinghouse achieved the \$14 million "target" savings in the performance criteria, then they would have met the 25 percent Superior Performance Standard for PBI 96-6. He also wrote:

"The lack of preciseness solely in the PBI language is not a valid basis for denial of payment of earned incentive fee given the other supporting documentation and the fact that the DOE oversight staff and the contractor have validated the intent of the parties both verbally and through written documentation. Therefore, in view of the above facts, and after consultation with my legal staff, we have concluded the preponderance of the evidence indicates WSRC [Westinghouse] met the intended standards for both PBl's and was entitled to the payment of $\$ 2.145 \mathrm{M}$ paid under these two PBI's."

We concluded there is no basis for recovering PBI fees in this case. Despite the earlier statements of two Savannah River officials and the inconsistency between the "Performance Standards" and "Performance Criteria," the Acting Manager of Savannah River stated that Savannah River Staff had conveyed to Westinghouse, both verbally and through written documentation, that a "Superior" performance fee would be paid for a cost savings of $\$ 14$ million under PBI 96-6 and an additional $\$ 7$ million under PBI 96-18. 
Recommendation

Management Comment

Inspector Comment
We recommend that the Manager, Savannah River Operations Office:

Recommendation 1: Ensure that PBI requirements are clearly written, and that "Performance Criteria" are consistent with the requirements in the "Performance Standards."

The Acting Manager, Savannah River concurred with the recommendation, and stated that: "I concur the language utilized in the PBI itself, as well as the formula for evaluation, was not clearly stated and clarity of PBI requirements is recognized as an area for improvement."

We consider management's statements regarding Recommendation 1 to be responsive. 
2. PBI Fee Paid For Work Which Did Not Meet PBI's Stated Requirement
PBI 96-11, entitled "Prepare Facilities and Personnel for Research Reactor Fuel Storage," required Westinghouse to "Demonstrate L-Reactor readiness for research reactor fuel storage by maintaining average water chemistry ... and successfully unloading two casks by $9 / 1 / 96$ for $\$ 380,000$." This date was subsequently modified to September 14, 1996.

Westinghouse notified Savannah River on August 30, 1996, that the L-Basin, associated with the L-Reactor, was ready to receive spent fuel. In an August 30, 1996, letter, Westinghouse's Vice President and Manager of Excess Facilities and Reactor Fuel Storage Program wrote to Savannah River's Assistant Manager for Defense Programs, and stated that:

"This memorandum is to inform the Department of Energy (DOE) that L-basin has been declared ready to receive Domestic and Foreign Research Reactor (DRR/FRR) Spent Nuclear Fuels (SNF). L-Basin readiness is consistent with the Excess Facilities and Reactor Fuel Storage Program Division FY96 Milestone, LRC02. WSRC has completed both the physical modification of the L-Basin and the related readiness assessment activities necessary to support this declaration...."

Although Westinghouse notified Savannah River that L-Basin was ready to receive Domestic and Foreign Research Reactor Spent Nuclear Fuels, the decision was made by DOE to suspend any movement of spent fuel pending resolution of a lawsuit filed by the State of South Carolina to block shipments of Foreign Research Reactor (FRR) Spent Nuclear Fuel to the Savannah River Site. Because of this decision, Savannah River waived the $\mathrm{PBI}$ requirement to demonstrate L-Reactor readiness by "successfully unloading two casks." Instead, Savannah River approved payment of the PBI on October 25, 1996, after observing dry-run exercises at the facility. The Savannah River technical reviewer noted on the approval form that "movement of fuel to L-Basin blocked by DOE-HQ due to ongoing lawsuit. WSRC would, in all likelihood, have met the milestone had this restraint not been imposed..."

However, our inspection found documentation which indicated that, contrary to its August 30,1996, letter, Westinghouse was 
not ready to receive all shipments of Spent Nuclear Fuel at L-Basin.

Specifically, the Savannah River Award Fee Board Report for the six-month period ending March 31, 1997, cited "Delays in LBasin Readiness" as a "Notable Deficiency." The report's narrative discussed this "Notable Deficiency," stating that:

"Although good support for the FRR lawsuit was provided by the contractor, the L-Basin was not ready to receive fuel as stated in the contractor's letter of August 30, 1996. In fact, fuel was not transferred from RBOF [Receiving Basin Off-site Fuels] to L-Reactor, for approximately five weeks following successful resolution of the lawsuit. The delays were due to incomplete analysis for the Nuclear Safety Data Sheet and the need to perform a Dropped Fuel Analysis. In addition, a procedure for the unloading of a fuel cask was not developed."

We discussed this comment with an official in Savannah River's Reactors and Spent Fuel Division who said that the "deficiency" principally pertained to delays in being able to properly receive "on-site" shipping casks used to transfer spent nuclear fuel between Savannah River facilities. This official said that Westinghouse had performed its dry-run assessments based upon a different "off-site" shipping cask. He said that, while LBasin had not been ready for the "on-site" cask, the approval by Westinghouse and Savannah River was essentially validated by L-Basin successfully receiving spent fuel from an "off-site" cask on January 30, 1997.

In a draft of this report we had concluded that the $\$ 380,000$ incentive fee paid for PBI 96-11-2 should be recovered. We had based this on the language of the $\mathrm{PBI}$, which did not specify receiving fuel from "offsite" versus "onsite" locations. The PBl's performance criteria simply stated "Demonstrate L-Reactor readiness for research reactor fuel storage by.... successfully unloading two casks by $9 / 1 / 96$ for $\$ 380,000$." We believed that the language of the PBI should have been the determining factor. 
In commenting on the draft report, however, the Acting Manager, Savannah River wrote that the language of this PBI was imprecise. He also discussed the key issue of whether PBI 96-11-2 was intended to prepare the L-Basin for receipt of fuel from both onsite and offsite locations, or just from offsite locations. He stated that the PBI was only intended to address the receipt of fuel from "offsite", and not "onsite" which utilized a differently configured shipping cask. He said that this was evidenced by the use of an "offsite" cask in the exercises conducted to validate L-Basin's preparedness. He wrote that the Award Fee Board Report addressed a deficiency involving an "onsite" shipment, and therefore did not pertain to PBI 96-11-2. $\mathrm{He}$ also wrote that both DOE-Savannah River and the contractor clearly understood the scope of work to be associated with receipt of spent nuclear fuel originating from offsite facilities. He wrote that:

"Based upon the consistency of the information..., and most importantly based upon the written and verbal assurances of DOE-SR staff members that the intent of this PBI was to prepare L-Basin for receipt of offsite casks, I have determined that the contractor satisfied the intent of PBI 96$11-2$ and was properly paid the $\$ 380,000$ provided for in the PBI."

We concluded, therefore, that there was no basis for recovering PBI fees in this case because DOE Savannah River had provided written and verbal assurances that the intent of this $\mathrm{PBI}$ was to prepare the L-Basin for receipt of offsite casks. The Acting Manager, Savannah River wrote that the PBI language in this case was not precise, and has acknowledged in response to Recommendation 1 that clarity of $\mathrm{PBI}$ requirements is recognized as an area of improvement. Therefore, no additional recommendation is required. 
3. New Sources of Funding Were Double-Counted Towards Two PBIs
PBI 96-14 entitled "Achieve Recognition of Technical Capability to Enhance DOE Special Missions, " and PBI 96-15 entitled "Additional Sources of Funding for SRTC [Savannah River Technology Center]" both had the objective of achieving additional sources of funding for their respective incentive program. In both PBIs, Westinghouse could earn an incentive fee by obtaining additional funding from other DOE sources and for PBI 96-15, non-DOE sources.

We noted in our inspection that three items of new funding totaling $\$ 3,280,000$ were counted towards achieving both PBI 96-14 and PBI 96-15. These three items were:

$$
\begin{aligned}
& \$ 2,580,000 \text { for Accelerator Production of Tritium } \\
& 500,000 \text { for Plutonium Conversion } \\
& 200,000 \text { for Spent Nuclear Fuel } \\
& \$ 3,280,000 \text { Total }
\end{aligned}
$$

We were told by both Savannah River and Westinghouse officials that Westinghouse could designate funding meeting the objectives of both PBI 96-14 and PBI 96-15 to the PBI of its choice, but that the funding could not be double counted towards achieving both PBIs. We were also told that in the event of a double counting situation, Westinghouse could apply the funding to whichever PBI would provide them with the most incentive fee.

We discussed the double counting of the above three items with a Westinghouse official. This official indicated that if double counting had occurred in achieving both PBI 96-14 and $\mathrm{PBI}$ 96-15, Westinghouse would request that the required adjustment be taken against $\mathrm{PBI}$ 96-14, since this would result in the least financial impact. We were informed by Savannah River officials that this issue had been referred to the Savannah River Chief Counsel for review. 
Recommendation

Management Comment

Inspector Comment
We recommend that the Manager, Savannah River Operations Office:

Recommendation 2: Review for recovery incentive fees paid to Westinghouse as a result of new funding being double counted towards achieving both PBI 96-14 and PBI 96-15.

The Acting Manager, Savannah River agreed that new funding was inappropriately counted towards the achievement of both PBI 96-14 and PBI 96-15. He stated that they have already modified the existing Award Fee Plan policy to prohibit such occurrences in the future, and that Savannah River has recovered $\$ 67,860$ in incentive fees from Westinghouse.

We consider management's statements regarding Recommendation 2 to be responsive. 


\section{Appendix}

Scope

Methodology
The inspection was performed at the Savannah River Operations Office in Aiken, South Carolina, from March through December 1997.

To accomplish the inspection objective, we:

- Evaluated the available guidance for establishment and implementation of the Performance Blased Incentive Program at the Savannah River Operations Office.

- Evaluated the goals established for specific Performance Based Incentive projects and the analysis performed by the Savannah River Operations Office to justify specific Performance Based Incentive award amounts.

- Evaluated whether the stated objectives of selected Performance Based Incentives were achieved.

The inspection was conducted in accordance with the "Quality Standards for Inspections" issued by the President's Council on Integrity and Efficiency. As part of our inspection, w/e interviewed Savannah River Operations Office and Westinghouse officials. Our inspection also included a detailed review of the files of the Award Fee Coordinator, the Contracting Officers, and the Program Managers for 19 of the 39 Performance Based Incentives established in Fiscal Year 1996. 


\section{CUSTOMER RESPONSE FORM}

The Office of Inspector General has a continuing interest in improving the usefulness of its products. We wish to make our reports as responsive as possible to our customers' requirements, and, therefore, ask that you consider sharing your thoughts with us. On the back of this form, you may suggest improvements to enhance the effectiveness of future reports. Please include answers to the following questions if they are applicable to you:

1. What additional background information about the selection, scheduling, scope, or procedures of the audit would have been helpful to the reader in understanding this report?

2. What additional information related to findings and recommendations could have been included in this report to assist management in implementing corrective actions?

3. What format, stylistic, or organizational changes might have made this report's overall message more clear to the reader?

4. What additional actions could the Office of Inspector General have taken on the issues discussed in this report which would have been helpful?

Please include your name and telephone number so that we may contact you should we have any questions about your comments.

Name

Date

Telephone

Organization

When you have completed this form, you may telefax it to the Office of Inspector General at (202) 5860948, or you may mail it to:

Office of Inspector General (IG-1)

Department of Energy

Washington, DC 20585

ATTN: Customer Relations

If you wish to discuss this report or your comments with a staff member of the Office of Inspector General, please contact Wilma Slaughter at (202) 586-1924. 
The Office of Inspector General wants to make the distribution of its reports as customer friendly and cost effective as possible. Therefore, this report will be available electronically through the Internet at the following alternative address:

Department of Energy Human Resources and Administration Home Page http://www.hr.doe.gov/ig

Your comments would be appreciated and can be provided on the Customer Response Form attached to the report.

This report can be obtained from the

U.S. Department of Energy

Office of Scientific and Technical Information

P.O. Box 62

Oak Ridge, Tennessee 37831 